\title{
Postoperative Lumbar Pyogenic Spondylodiscitis: An Institutional Review
}

\author{
Mantu Jain ${ }^{1}$ Rabi Narayan Sahu ${ }^{2} \quad$ Amrit Gantaguru ${ }^{1} \quad$ Sudhanshu Sekhar Das ${ }^{1} \quad$ Sujit Kumar Tripathy ${ }^{1}$ \\ Ashish Pattnaik ${ }^{2}$ \\ ${ }^{1}$ Department of Orthopedics, All India Institute of Medical Sciences, \\ Bhubaneswar, Odisha, India \\ 2Department of Neurosurgery, All India Institute of Medical \\ Sciences, Bhubaneswar, Odisha, India \\ Address for correspondence Mantu Jain, MS, DNB, Department of \\ Orthopedics, All India Institute of Medical Sciences, Bhubaneswar \\ 751019, Odisha, India (e-mail: montu_jn@yahoo.com).
}

J Neurosci Rural Pract 2019;10:511-518

\begin{abstract}
Background Postoperative discitis (POD) remains a dreaded complication in the present era of asepsis. The treatment has been traditionally conservative, but the safety of spinal implants in infective settings has prompted the surgeons to provide rigid immobilization for promoting healing. A major concern in a country like ours is huge patient inflow and long waiting list added to the woe of patient's refusal for a second operative intervention after a first undesirable outcome.

Objectives The aim of the study was to evaluate the functional and radiological outcome of conservative management of POD and determine the methods of prevention. Settings and Design A retrospective case study series in a tertiary-level hospital. Materials and Methods Between January 2015 and 2017, 12 cases of POD (10 own and 2 referred) were managed and followed up clinically, radiologically, and with laboratory investigation. Two cases were managed surgically-one with kyphotic deformity and the other with discharging pus. Rest were managed conservatively with analgesics and intravenously followed by oral antibiotics. At 1-year follow-up, patient satisfaction was evaluated using the MacNab outcome assessment.

Statistical Analysis The descriptive data were analyzed mainly by descriptive statistics using mean, median, standard deviation, and interquartile range.

Results Mean follow-up in our series was 15.2 months. Except for two operated cases, we did not go for the invasive procedure for isolation of organism in any of our cases. The total duration of antibiotic in our series was for the mean of 7.3 weeks.

Keywords

- discitis

- lumbar discectomy

- management

- postoperative

- pyogenic Visual analog scale score returned from 8 initially to baseline and at final follow-up-4 excellent, 6 good, and 2 had fair outcome. There was no adverse outcome.

Conclusions The majority of POD can be managed conservatively. Surgery is reserved only for special cases. Magnetic resonance imaging is the investigation of choice for diagnosing discitis. Intraoperative use of gentamicin-mixed normal saline wash reduces the incidence of discitis.
\end{abstract}

\section{Introduction}

Postoperative discitis (POD) is a dreaded complication following lumbar disc surgery. First recognized in 1953 by Turnbull as a clinical entity, ${ }^{1}$ it continues to haunt every spine surgeon in the present era of ever-increasing concern for surgical safety and asepsis. POD takes the form of a closed, deep-space infection, at the site of the surgery, of the nucleus pulposus and involves the cartilaginous end plate and the vertebral body following discectomies. ${ }^{2}$ The reported incidence is $<1 \%$ in the West ${ }^{3,4}$ but 4 to $10 \%$ in India. ${ }^{5-8}$ The cause is largely iatrogenic, although spontaneous discitis has also 
been described. Among the factors related to surgery, the main ones are damage to the lower and upper end plates following disc space curettage, inadvertent introduction of germs, and instability. ${ }^{9}$ Some patient-related intrinsic factors such as diabetes, smoking, malnourishment, and morbid obesity also need to be optimized to lower the possibility of POD. ${ }^{4}$ Prolonged catheterization and prolonged stay in hospital increase the risk of nosocomial infection. ${ }^{10}$ Whether truly aseptic or of an infective etiology, the causal organism has been isolated only in half of the cases. ${ }^{5,11}$ The diagnosis is, mainly clinical, based on symptoms and signs and supported by laboratory tests and radiological parameters. The treatment has been traditionally conservative, but the safety of spinal implants in infective settings has been tempting the surgeons to prescribe rigid immobilization of the affected segments to promote healing. ${ }^{12-14}$ A major concern in a country such as India is apprehension on the part of patients and their refusal to undergo a second operative intervention when the outcome of the first one has been adverse. The problem is aggravated by a huge inflow of patients and a long waiting list in a public sector hospital such as ours and the additional expenses associated with surgery, which largely influence decision making by patients. It is against this background that this paper seeks to review the outcome of conservative management in patients with POD and to define the absolute surgical indications for such patients.

\section{Materials and Methods}

This study is a retrospective audit of the management of patients with POD who had been admitted to our tertiary care institute between January 2015 and January 2017. The data were retrieved from records after approval by the hospital's ethical committee. Only those patients who had undergone single-level lumbar discectomy were included in the study; those with multiple-level discectomy, spontaneous discitis, and implant-associated discitis were excluded.

The diagnosis of POD was based on the clinical and radiological parameters. Patients with clinical symptoms and signs suggestive of discitis after surgery were evaluated on the basis of blood and radiological investigations. The severity of pain was measured using the visual analog scale (VAS) score. Radiological investigations included X-rays to record an anteroposterior view and lateral views to document endplate erosion, cavitation, reduction in disc space, and instability if any, supplemented with computed tomography (CT) if the radiographs failed to provide a definitive diagnosis or with magnetic resonance imaging (MRI) with gadolinium contrast-enhanced pictures taken during the postoperative period. Blood tests included complete blood count, erythrocyte sedimentation rate (ESR), C-reactive protein (CRP)-quantitative blood cultures, and human immunodeficiency virus status.

The patients were given empirical antibiotics based on the antibiogram data available at our hospital. We followed the regimen suggested by Basu et al, ${ }^{5}$ namely, intravenous (IV) antibiotics for 3 weeks followed by oral antibiotics for the next 3 weeks but customized or adjusted as required. The patients were switched to specific antibiotics if the culture proved sensitive to a particular antibiotic and were advised bedrest followed by gradual mobilization using spinal orthosis to the extent they could tolerate.

The antibiotics included vancomycin or linezolid for gram-positive organisms, amikacin or netromycin for gram-negative organisms, and metronidazole or tinidazole for anaerobic organisms. Surgical intervention in the form of stabilization was performed for patients with bony destruction leading to instability or deformity and with discharging wounds. The patients were evaluated using serial ESR, CRP, and X-rays at 3-week, 6-week, 3-month, and then at 6-month intervals. Patient satisfaction was assessed using the MacNab assessment criteria ${ }^{15}$ in terms of the presence and degree of pain and the ability to resume normal activities.

\section{Results}

Twelve patients, 10 of them institutional ( $8 \%$ of the 124 surgeries) and 2 referred from elsewhere, had been admitted between January 2015 and January 2017 with symptoms suggestive of POD. Of the 12 patients, 7 (58\%) were male and $5(42 \%)$ were female. The mean age at the time of admission was 42 years and ranged from 25 to 53 years. The patients presented themselves between 2 and 8 weeks (average: 3.5 weeks) after the discectomy. Three (25\%) of the patients suffered from associated diabetes mellitus type II, one (8\%) was malnourished, two (17\%) were obese (body mass index >35), and two (17\%) were chronic smokers.

In all the patients, low back pain was associated with paraspinal spasm. The median VAS score at the time of admission was 8 (interquartile range [IQR]: 8.0-9.0). Radiculopathy was noted in four (33.3\%) patients and one (8.3\%) patient had draining frank pus from the wound. No patient showed fever $\left(>98.5^{\circ} \mathrm{F}\right)$. The median ESR at the time of admission was 67 (IQR: 46-79), CRP was 22 (IQR: 16.75-29), and the radiographs showed five (42\%) patients with the affected level of L4-L5 and seven (58\%) with L5-S1. Notable radiological findings were end-plate erosion and reduced disc space, and the patients showed deformity. Dynamic views were too painful and therefore were not undertaken. MRI showed the characteristic hypointense T1, hyperintense T2, and contrast-enhanced $\mathrm{T} 1$. The surgical procedures were hemilaminectomy in six (50\%) patients, laminectomy in four (33\%), and fenestration in two (17\%). None of the patients showed any associated epidural abscess or neuro deficit. Four (33.3\%) patients tested positive for bacteria following blood culture but none tested positive for Fungi. Of the four who tested positive, three (25\%) showed Staphylococcus aureus (2 methicillin-susceptible $S$. aureus and one methicillin-resistant $S$. aureus) and one (8\%) showed Pseudomonas aeruginosa. None of them had a mixed flora infection. Ten (83\%) patients received conservative treatment and two (17\%) were operated for posterior surgical stabilization along with debridement, with the indications being kyphosis in one and a discharging wound in the other. Both these patients were operated upon immediately after admission. None of the 10 patients being managed conservatively had failure to response requiring surgical 
treatment. The serial ESR and CRP returned to their baseline values by 3 weeks in nine (75\%) patients but showed a downward trend in three $(25 \%)$ and did not return to the baseline values: Of these three, two received extended IV antibiotics for 2 weeks and one for 3 weeks until these acute-phase reactants had normalized. Furthermore, the responder nine (75\%) patients were given oral antibiotics for 3 weeks and the three late responders (25\%) for 6 weeks. Thus, the total duration of the antibiotic treatment was 6 to 12 weeks with a mean of 7.3 weeks. Of the two patients who had been operated upon for posterior surgical stabilization along with debridement, one showed $P$. aeruginosa infection from the discharging pus and from the fluid deep in the wound, although the patient had tested negative initially on blood culture. The other patient showed no growth-neither pyogenic nor fungal and nor tubercular. In $5(42 \%)$ of the 12 patients, we were able to isolate the offending germs. In all the patients, who had been mobilized with braces by 1 to 2 weeks as tolerable, VAS scores fell ( - Fig. 1) but were dramatically so in the two (17\%) patients who had been operated upon. The mean follow-up duration was 15.2 months and ranged from 12 to 18 months. Four (33.3\%) patients (two who had been operated upon and two who had been under conservative management) attained fusion and the rest showed reformation and sclerosis of the end plate although with a reduction in joint space. When subjected to the MacNab outcome assessment at the final follow-up, four (33\%) patients rated their experience as excellent, six (50\%) as good, and two (17\%) as fair. On the whole, two (17\%) patients had to change the nature of their work. - Figures $\mathbf{2}$ to $\mathbf{5}$ show the imaging profiles of some of the patients.

\section{Discussion}

Postsurgical discitis is a rare but extremely serious complication following discectomy. Some authors have tried to differentiate POD into septic and aseptic forms. Aseptic discitis arises as a result of traumatization of the disc and vascular compromise during surgery. ${ }^{16}$ However, even this is believed by some as a result of infection by organisms of low virulence. ${ }^{17}$ In the absence of any specific differentiating MRI features, ${ }^{18}$ nonelevation of the inflammatory markers (ESR and

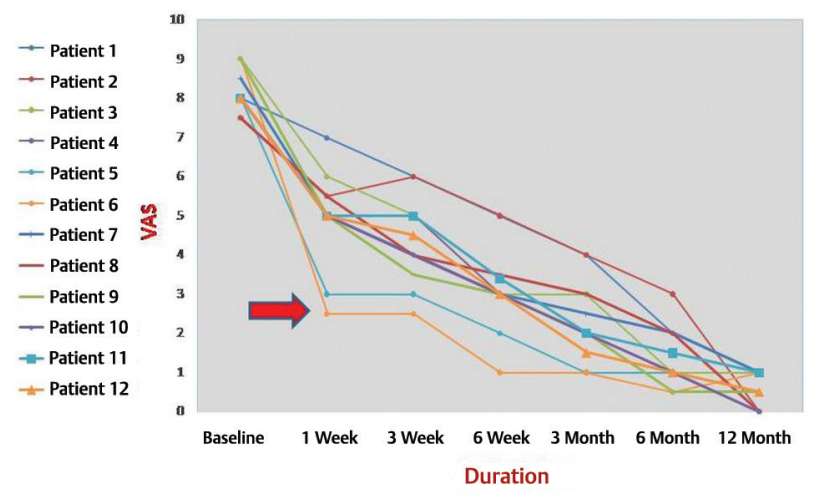

Fig. 1 Visual analog scale score of 12 patients. Arrow shows the dramatic improvement in two patients who were operated upon.

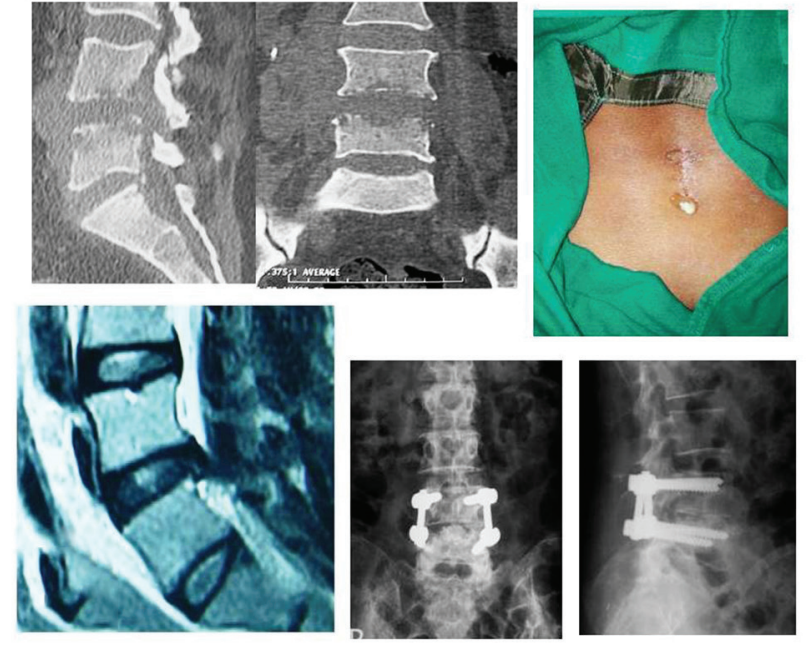

Fig. 2 Clinicoradiological profile of a patient who had discharging pus and was debrided and subjected to posterior instrumentation.
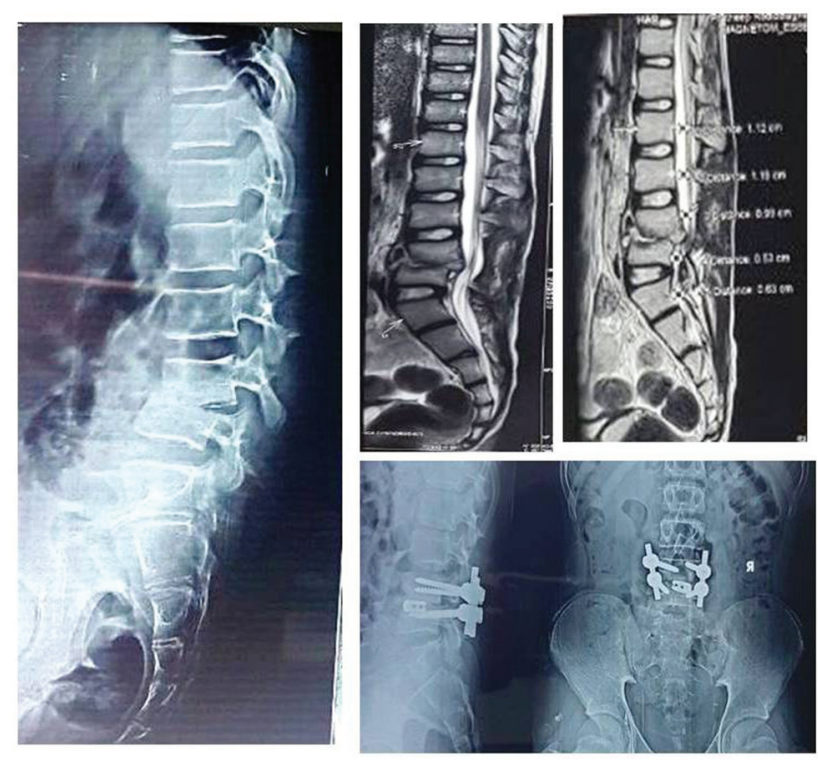

Fig. 3 Radiological profile of a patient who had kyphosis and was treated with transforaminal lumbar interbody fusion surgery.
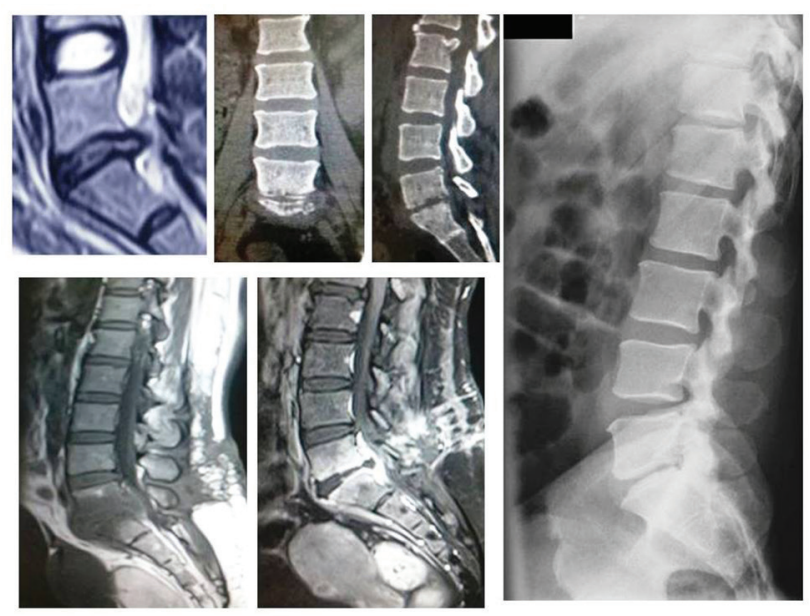

Fig. 4 L5-S1 discitis that ended in fibrous ankylosis. 


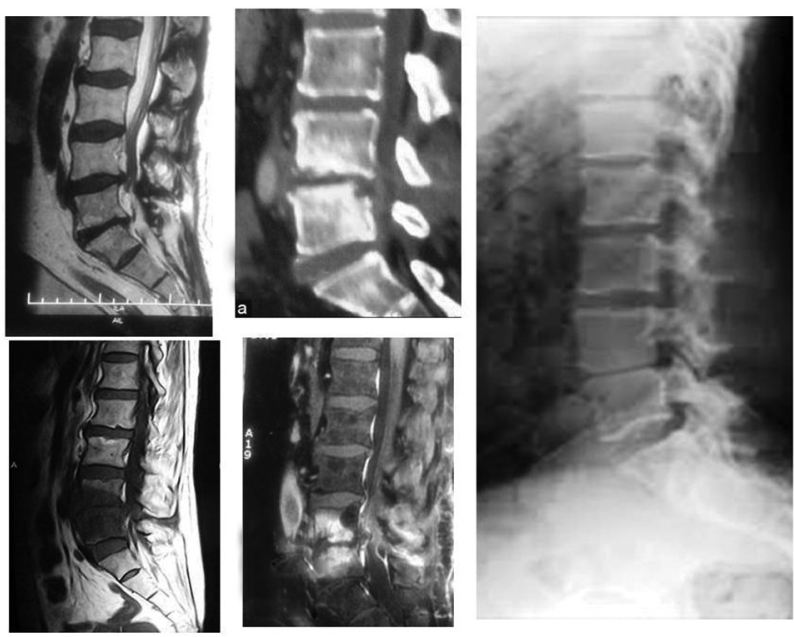

Fig. 5 L4-L5 level discitis that was managed conservatively and led to fibrous ankylosis at the end.

CRP) can only suggest an aseptic noninfective etiology. In our series, all the patients had elevated ESR and CRP; we therefore believe all those cases as a septic form of discitis.

Multiple risk factors that increase the incidence of discitis have been identified; these include diabetes, malignancy, smoking, chronic alcoholism, malnutrition, and intake of steroids. ${ }^{2}$ In the present study, we identified at least 7 (58\%) out of 12 as having at least one confounding factor. Infection of the respiratory tract or the urinary tract can increase the risk further, and it is common for patients to have prolonged hospitalization with indwelling catheters, which makes the patients prone to nosocomial infections. ${ }^{19,20}$

Recurrence of pain following discectomy has been attributed to wrong-level discectomy (3.3-13\%), residual disc, postsurgical instability of spinal segment, and sometimes, the persistence of stenosis of the lateral recess. ${ }^{21,22}$ Diagnosing discitis continues to be difficult, given the lack of established criteria, and one has to supplement clinical findings with radiological and biochemical markers. Back pain and muscle spasm are the most consistent features of discitis, supposed to be present in almost all cases.5.,23 The mean VAS score at the time of admission was 8 in our cohort. The intensity of pain can vary. Puranen et al reported completely disabling pain, which was aggravated by movement and coughing in eight of their patients. ${ }^{16}$ Similar findings, a mean VAS score of 8.5, were also reported by Basu et al. ${ }^{5}$ In contrast, Hopkinson et al noted mild pain in many patients. ${ }^{24}$ Paravertebral muscle spasm was consistently found in 75 to $100 \%$ of cases. ${ }^{5,7,16}$ Almost all of our patients suffered from disturbed sleep: any sudden turning in bed during sleep would cause excruciating pain, forcing them to wake up. The pain was also aggravated by coughing, sneezing, and straining during defecation. Signs of tension in root, as seen in patients given the straight-legraising test, was seen in five (42\%) of our patients, but none showed any motor or sensory disturbance. Fever too is a highly variable feature and ranged from 11 to $68 \% 5,25,26$; it is therefore not a reliable feature, and we found no patient who had a body temperature $>38^{\circ} \mathrm{C}$ at the time of admission.
One of the most dependable markers of inflammation is CRP. Levels of CRP and ESR follow a predictable pattern following discectomy: CRP peaks by the second day and returns to normal by 5 to 14 days, whereas ESR peaks by the fifth day and slowly reverts to the baseline by 21 to 42 days. ${ }^{27}$ Therefore, an abnormally high CRP, 2 weeks after surgery, must alert the surgeon. In our study, the mean duration to reach the peak was 3.5 weeks, pointing clearly to infection. The decrease in both CRP and ESR following treatment and the clinical improvement further strengthened the potential of these two parameters as important prognostic markers.

Contrast-enhanced MRI is the gold standard for imaging modality. However, it takes a while for typical X-ray or CT findings of discitis to appear, leading to delays in diagnosis. Compared with plain film, $\mathrm{CT}$ is more sensitive in diagnosing discitis. ${ }^{28}$ Basu et al noticed decreased disc height and changes in the end-plate in radiographs taken at 6 to 8 weeks and end-plate erosion in CT scan at 3 to 6 weeks. ${ }^{5}$ Hopkinson et al failed to diagnose discitis through $\mathrm{CT}$ in 10 of their patients. ${ }^{24}$ In discitis, subtle changes develop in MRI as early as 3 to 5 days, ${ }^{29,30}$ and MRI can also pick up an abscess, which is considered as an indication for surgical exploration. ${ }^{29}$ However, these changes should be interpreted with caution, because they resemble such other noninfective conditions as acute end-plate injury during surgery, remnants of an extruded disc, and Modic Type I changes..$^{31}$ Consequently, features that can clinch the diagnosis of discitis are (1) typical MRI findings, (2) a clinically nonimproving patient, and (3) elevated inflammatory markers. We subjected all our patients to MRI and do so routinely in all cases or back pain after surgery, and this additional test may have revealed many subclinical cases-we strongly believe that discitis has been underreported.

The adult disc is avascular, and direct introduction of a pathogen during surgery is the most commonly accepted cause of POD., ${ }^{2,1932}$ Another possible pathway through which the malady can spread is through the Batson venous plexus, a network that can communicate with veins of vertebral bodies. ${ }^{2,19}$ Again, considering the avascularity of discs, the routine use of preoperative antibiotics has been challenged. Yet, antibiotics do reach disc space, and Lang et al found that inhibitory concentrations of ceftriaxone reached the disc space when $2 \mathrm{~g}$ of ceftriaxone was used. ${ }^{33}$ The incidence of discitis is definitely higher without prophylactic use of antibiotics. Tai et $\mathrm{al}^{34}$ recommended $5 \mathrm{mg} / \mathrm{kg}$ of gentamicin to reduce the risk of discitis. We routinely use gentamicin $500 \mathrm{mg}$ and ceftriaxone $2 \mathrm{~g}$, both as a single dose, before inducing anesthesia. Out of 10 cases of POD in this study, seven ( 7 out of 64 discectomies) were encountered in the first year-an unusually high proportion compared with that reported in other studies. A factor common to these 10 cases was that all were the last cases in the long surgical list for the day in a busy operation theater, which meant longer time ( $>1.5$ hours) by the already-exhausted surgeons. Being a teaching and training hospital, the number of footfalls in the operating theater is usually high (including the paramedics and medics) possibly leading to higher rates of infection. Hamdan reported below-the-standard operating rooms, and we accept that the same may be the case in our hospital too; moreover, for 
that matter, in other public hospitals across India. ${ }^{29}$ However, learning from Rohde et $\mathrm{al}^{2}{ }^{2}$ we have begun to routinely irrigate disc space with normal saline mixed with gentamicin every 15 minutes during the operation and to use gentamicin-soaked Gelfoam in disc space after surgery. Since introducing this practice, we had only three cases ( 3 cases of 60 discectomies) of discitis in the second year.

The time between the index surgery and signs of discitis is highly variable, ranging from 2 days to 6 months. ${ }^{24,25} \mathrm{We}$ believe that the time depends not only on the virulence of the organism and the degree of immunity of the patient but also on the surgeon's ability to pick up the cases in their early stages. Hamdan was quicker in diagnosing the cases compared with most of the other surgeons and also very aggressive in providing surgical debridement to patients failing to respond conservatively by 4 days. ${ }^{29}$ The mean duration for the development of symptoms in our series was 3.5 weeks. Ninety-five percent of the cases of lumbar disc herniation occur at L4-L5 and L5-S1 levels ${ }^{35}$ and were the most common sites of discitis across all studies: the present study was no exception, with seven (58\%) cases at L5-S1 and five (42\%) at L4-L5. Greater incidence at either level may be merely a matter of chance and bears no correlation with any other feature.

Isolating the causal organism is a matter of debate. With a second invasive procedure, the yield may be positive in only half the cases ${ }^{2,32,36}$ : CT-guided biopsy has poor results, with only 9 of 25 (36\%) CT-guided biopsies being positive, as reported by Enoch et al, ${ }^{37}$ whereas percutaneous endoscopic discectomy and drainage (PEDD) is far superior in identifying causal pathogens. The proportion of positive results from PEDD has been reported to be as high as 86 to $90 \%{ }^{38-40}$ Yang et al reported positive results from culturing in $90 \%$ of patients in a PEDD group compared with only $47 \%$ in a CT-guided biopsy group..$^{38}$ An added advantage of PEDD is immediate relief of pain owing to debridement and irrigation of disc space, which accompany the procedure..$^{38}$ It is also noteworthy that Tronnier et al, on culturing all their 412 postdiscectomy samples, found $17 \%$ of the cases to be positive but only one patient developed discitis. ${ }^{19}$ Therefore, we maintain that it is not necessarily the isolated organism that causes discitis and subjecting a patient to a second invasive procedure to identify the pathogenesis not justified. We cultured samples from only two of our patients who had undergone debridement: one culture tested negative and the other tested positive for Pseudomonas. Staphylococcus aureus and Staphylococcus epidermidis, in that order, have been the leading causes of discitis as reported in several studies.,5,6,19,25 Infrequently, Mycobacterium tuberculosis has been found associated with discitis. ${ }^{4}$ Basu et al reported only a single case of tuberculosis (TB) that did not respond to conservative management in their series. ${ }^{5}$ In regions such as ours, where TB is endemic, reactivation of latent TB always remains a potential threat. Fungal infections, although rare, may also follow discectomy, as reported by Zou et al, the most common causes being Candida and Aspergillus. ${ }^{41}$ Fungal discitis does not show any abscess in MRI but is almost always associated with multilevel bone destruction. ${ }^{5}$ In our opinion, those patients who do not respond to conservative management must be evaluated for these atypical infections. We immediately started all our patients on empirical antibiotics according to the antibiogram of our hospital. Before starting the antibiotic regimen, we routinely cultured blood and urine samples of all our patients. Blood culture was positive in $33 \%$ of our patients, a figure close to that reported in literature. ${ }^{28,29}$

Bedrest with IV antibiotics followed by oral antibiotics has been the traditional treatment strategy for discitis. Keeping in mind the limited diffusion of antibiotics across disc space, a prolonged antibiotic regimen seems logical.,33,34 Many studies have advocated a minimum of 6 weeks of IV therapy, and any duration shorter than that has led to poorer results. ${ }^{36}$ Basu et al found a 3-week IV regimen to be effective in the majority of cases; those who failed to respond were operated upon. ${ }^{5}$ We started all the patients on a 3-week regimen and administered extended IV doses to those who had suboptimal response (delayed responders) but showed a decreasing trend of biomarkers until the level of CRP reverted to its normal value. We also monitored the renal and liver parameters of those patients regularly. Oral antibiotics were continued for 3 weeks for those who showed normal response and for 6 weeks for those who showed a delayed response.

Surgical debridement was undertaken for only two of our patients who showed clear indications at the time of admission, and hence there was no point in waiting. Some studies along with their indications of surgery are shown in - Table 1. Basu et al operated upon five patients who showed suboptimal response to IV by 3 weeks. ${ }^{5}$ Since earlier studies have recommended 6 weeks of IV, we thought it imperative to wait until 6 weeks; all three of our slow responders had settled by then without operation. In both of our operative cases, we performed transforaminal lumbar interbody fusion because it is difficult to assess instability in discitis. Those with more experience have performed posterior, transforaminal, and even extreme lateral interbody fusion. ${ }^{42-44}$ Although there is no comparative study to find out superiority of one over another to our knowledge, all studies have confirmed the safety of metallic instruments and cages in pyogenic discitis. One reported advantage of surgery is that it allows early mobilization even by 48 hours, ${ }^{5-7}$ but this benefit must be weighed against psychological stress and postprocedural complications. It seems that even with surgery, a prolonged course of antibiotics is inevitable, ${ }^{5-7,29}$ making the treatment more expensive, especially for the poorer patients. Rawling et al reported ankylosis or painless fibrous union in $75 \%$ cases of POD at a 2-year follow-up on patients who had been treated conservatively. ${ }^{45}$ We noted that patients were apprehensive about a second surgical procedure and given the long waiting list that plagues state-run institutions, we mostly opted for conservative management.

Despite all the advances, prognosis in POD remains tentative. Iversen reported persistent backache in all his patients, ${ }^{23}$ whereas Basu et $\mathrm{al}^{5}$ and Santhanam and Lakshmi ${ }^{7}$ reported good outcomes in all their patients, who resumed their normal daily activities within 6 months. In our group, four patients showed excellent outcome; three patients, although they continue to have back pain, do not require any nonsteroidal anti-inflammatory drugs now; and two had to change 
Table 1 Reported studies on discitis over the past 15 years (2002-2018) with percentages and indications of surgery

\begin{tabular}{|c|c|c|c|c|c|c|c|}
\hline $\begin{array}{l}\text { Serial } \\
\text { number }\end{array}$ & $\begin{array}{l}\text { Name of the } \\
\text { investigator }\end{array}$ & $\begin{array}{l}\text { Name of } \\
\text { the journal }\end{array}$ & $\begin{array}{l}\text { Year of } \\
\text { publication }\end{array}$ & $\begin{array}{l}\text { Num- } \\
\text { ber of } \\
\text { patients }\end{array}$ & $\begin{array}{l}\text { Number of oper- } \\
\text { ative patients }\end{array}$ & Instrumented & $\begin{array}{l}\text { Operative } \\
\text { indication }\end{array}$ \\
\hline 1 & $\begin{array}{l}\text { Deepak } \\
\text { Kumar Singh } \\
\text { et al }\end{array}$ & $\begin{array}{l}\text { Asian J } \\
\text { Neurosurg }\end{array}$ & 2018 & 31 & $\begin{array}{l}5(16 \%)= \\
\text { posterior }\end{array}$ & Yes & $\begin{array}{l}\text { Failure of } \\
\text { conservative } \\
\text { management }\end{array}$ \\
\hline 2 & R. Santhanam & Asian Spine J & 2015 & 18 & $\begin{array}{l}5(28 \%)= \\
\text { posterior }\end{array}$ & Yes & $\begin{array}{l}\text { Failure of } 4 \text { week } \\
\text { of conservative } \\
\text { management }\end{array}$ \\
\hline 3 & Adam $D$ et al & $\begin{array}{l}\text { Chirurgia } \\
\text { (Bucur) }\end{array}$ & 2014 & 24 & $13(54 \%)$ & No & $\begin{array}{l}\text { Open biopsy to } \\
\text { isolate germ }\end{array}$ \\
\hline 4 & $\begin{array}{l}\text { ShihChieh } \\
\text { Yang et al }\end{array}$ & $\begin{array}{l}\text { BMC Mus- } \\
\text { culoskeletal } \\
\text { Disord }\end{array}$ & 2014 & 32 & $\begin{array}{l}32(100 \%)=\text { PEDI } \\
6(18.75 \%)= \\
\text { further surgical } \\
\text { treatment like } \\
\text { anterior inter- } \\
\text { body fusion }\end{array}$ & $\begin{array}{l}\text { Not } \\
\text { mentioned }\end{array}$ & $\begin{array}{l}\text { Single-lev- } \\
\text { el infectious } \\
\text { spondylodiscitis, } \\
\text { postoperative in- } \\
\text { fectious spondylo- } \\
\text { discitis, advanced } \\
\text { infection with } \\
\text { epidural abscess, } \\
\text { psoas muscle ab- } \\
\text { scess, prevertebral } \\
\text { or paravertebral } \\
\text { abscess, multilevel } \\
\text { infectious spondy- } \\
\text { litis, and recurrent } \\
\text { infection after } \\
\text { anterior debride- } \\
\text { ment and fusion }\end{array}$ \\
\hline 5 & Fu TS et al & Biomed J & 2013 & $\begin{array}{l}\text { Review } \\
\text { article }\end{array}$ & Selective $=$ PEDD & No & $\begin{array}{l}\text { PEDD should be } \\
\text { considered an } \\
\text { alternative before } \\
\text { extensive anterior } \\
\text { surgery }\end{array}$ \\
\hline 6 & $\begin{array}{l}\text { Moon MS } \\
\text { et al }\end{array}$ & $\begin{array}{l}\text { J Orthop } \\
\text { Surg (Hong } \\
\text { Kong) }\end{array}$ & 2012 & 35 & $\begin{array}{l}4(11 \%) \\
1 \text { = simple } \\
\text { posterior wound } \\
\text { debridement } \\
2 \text { = anterior } \\
\text { surgery } \\
1 \text { = posterior in- } \\
\text { strument fusion } \\
6 \text { = percuta- } \\
\text { neous disc } \\
\text { aspiration }\end{array}$ & Yes $(3 / 4)$ & - \\
\hline 7 & $\begin{array}{l}\text { Hamdan TA } \\
\text { et al }\end{array}$ & Int Orthop & 2012 & 35 & $\begin{array}{l}29(83 \%)= \\
\text { re-exploration }\end{array}$ & No & $\begin{array}{l}\text { No response is } \\
\text { achieved after } \\
\text { 4-day conservative } \\
\text { treatment or pa- } \\
\text { tient's condition is } \\
\text { critical. }\end{array}$ \\
\hline 8 & $\begin{array}{l}\text { Saumyajeet } \\
\text { Basu et al }\end{array}$ & $\begin{array}{l}\text { Indian J } \\
\text { Orthop }\end{array}$ & 2012 & 17 & $\begin{array}{l}4(24 \%)(3= \\
\text { posterior de- } \\
\text { bridement and } \\
\text { fixation; } \\
1 \text { = percutane- } \\
\text { ous fixation) }\end{array}$ & Yes & $\begin{array}{l}\text { Failure of conser- } \\
\text { vative treatment } \\
\text { after } 3 \text { weeks }\end{array}$ \\
\hline 9 & Li J et al & $\begin{array}{l}\text { Arch Orthop } \\
\text { Trauma Surg }\end{array}$ & 2011 & $\begin{array}{l}34 \\
31= \\
\text { Lumbar }\end{array}$ & $31(91 \%)=$ PDD & No & $\begin{array}{l}\text { Obtaining suf- } \\
\text { ficient biopsy } \\
\text { material for his- } \\
\text { tological analysis } \\
\text { and culture }\end{array}$ \\
\hline
\end{tabular}


Table 1 (continued)

\begin{tabular}{|l|l|l|l|l|l|l|l|}
\hline $\begin{array}{l}\text { Serial } \\
\text { number }\end{array}$ & $\begin{array}{l}\text { Name of the } \\
\text { investigator }\end{array}$ & $\begin{array}{l}\text { Name of } \\
\text { the journal }\end{array}$ & $\begin{array}{l}\text { Year of } \\
\text { publication }\end{array}$ & $\begin{array}{l}\text { Num- } \\
\text { ber of } \\
\text { patients }\end{array}$ & $\begin{array}{l}\text { Number of oper- } \\
\text { ative patients }\end{array}$ & Instrumented & $\begin{array}{l}\text { Operative } \\
\text { indication }\end{array}$ \\
\hline 10 & Zou MX et al & $\begin{array}{l}\text { Clin Neurol } \\
\text { Neurosurg }\end{array}$ & 2005 & 10 & $\begin{array}{l}10(100 \%)(10= \\
\text { anterior debride- } \\
\text { ment and fusion } \\
\text { 3= addition- } \\
\text { al posterior } \\
\text { fixation) }\end{array}$ & $\begin{array}{l}\text { Fungal } \\
\text { spondylodiscitis }\end{array}$ \\
\hline 11 & $\begin{array}{l}\text { Bavinzski G } \\
\text { et al }\end{array}$ & $\begin{array}{l}\text { Neurosurg } \\
\text { Rev }\end{array}$ & 2003 & 17 & $\begin{array}{l}17 \text { (100\%) } \\
\text { microsurgical } \\
\text { debridement } \\
\text { with closed suc- } \\
\text { tion irrigation } \\
1=\text { re-de- } \\
\text { bridement } \\
\text { and posterior } \\
\text { instrumentation }\end{array}$ & $\begin{array}{l}\text { No except } \\
\text { one that was } \\
\text { redebrided }\end{array}$ & - \\
\hline 12 & $\begin{array}{l}\text { Hadjipavlou } \\
\text { AG et al }\end{array}$ & $\begin{array}{l}\text { Spine (Phila } \\
\text { Pa 1976) }\end{array}$ & 2002 & 2 & $\begin{array}{l}\text { 2(100\%) surgi- } \\
\text { cal debridement }\end{array}$ & No & \\
\hline
\end{tabular}

Abbreviations: PDD, percutaneous discectomy and drainage; PEDD, percutaneous endoscopic discectomy and drainage; PEDI, percutaneous endoscopic debridement and irrigation.

their profession and are now moderately active (one of these two had kyphotic deformity).

\section{Conclusions}

Despite our small sample, we believe that in a majority of cases, POD can be managed medically and surgical debridement should be reserved only for the resistant cases and those with clear indications for surgery. We do believe that isolation of the causal organism is absolutely necessary; discitis can be managed with empirical antibiotics following a hospital's standard antibiogram.. If diagnosed early and managed promptly, discitis can be managed satisfactorily. As resistance to antibiotics continues to increase, the management of discitis will prove increasingly difficult, and we must therefore seek ways to prevent it. Prophylactic antibiotics and careful washing of the wound definitely lower the risk of discitis.

\section{Funding}

None.

\section{Conflict of Interest}

None declared.

\section{References}

1 Turnbull F. Postoperative inflammatory disease of lumbar discs. J Neurosurg 1953;10(5):469-473

2 Rohde V, Meyer B, Schaller C, Hassler WE. Spondylodiscitis after lumbar discectomy. Incidence and a proposal for prophylaxis. Spine 1998;23(5):615-620

3 Cottle L, Riordan T. Infectious spondylodiscitis. J Infect 2008;56(6):401-412

4 Gerometta A, Bittan F, Rodriguez Olaverri JC. Postoperative spondylodiscitis. Int Orthop 2012;36(2):433-438

5 Basu S, Ghosh JD, Malik FH, Tikoo A. Postoperative discitis following single-level lumbar discectomy: our experience of 17 cases. Indian J Orthop 2012;46(4):427-433
6 Singh DK, Singh N, Das PK, Malviya D. Management of postoperative discitis: a review of 31 patients. Asian J Neurosurg 2018;13(3):703-706

7 Santhanam R, Lakshmi K. A retrospective analysis of the management of postoperative discitis: a single institutional experience. Asian Spine J 2015;9(4):559-564

8 Srinivas DB, Sekhar DD, Penchalayya DG, Murthy DK. Postoperative discitis-a review of 10 patients in a tertiary care neurosurgical unit. IOSR J Dent Med Sci 2016;15:1-4

9 Zink PM, Frank AM, Trappe AE. Prophylaxis of postoperative lumbar spondylodiscitis. Neurosurg Rev 1989;12(4):297-303

10 Rechtine GR, Bono PL, Cahill D, Bolesta MJ, Chrin AM. Postoperative wound infection after instrumentation of thoracic and lumbar fractures. J Orthop Trauma 2001;15(8):566-569

11 Onik G. Automated percutaneous biopsy in the diagnosis and treatment of infectious discitis. Neurosurg Clin N Am 1996;7(1):145-150

12 Abbey DM, Turner DM, Warson JS, Wirt TC, Scalley RD. Treatment of postoperative wound infections following spinal fusion with instrumentation. J Spinal Disord 1995;8(4):278-283

13 Arens S, Schlegel U, Printzen G, Ziegler WJ, Perren SM, Hansis M. Influence of materials for fixation implants on local infection. An experimental study of steel versus titanium DCP in rabbits. J Bone Joint Surg Br 1996;78(4):647-651

14 Chen WH, Jiang LS, Dai LY. Surgical treatment of pyogenic vertebral osteomyelitis with spinal instrumentation. Eur Spine J 2007;16(9):1307-1316

15 MacNab I. Negative disc exploration. An analysis of the causes of nerve-root involvement in sixty-eight patients. J Bone Joint Surg Am 1971;53(5):891-903

16 Puranen J, Mäkelä J, Lähde S. Postoperative intervertebral discitis. Acta Orthop Scand 1984;55(4):461-465

17 Fraser RD, Osti OL, Vernon-Roberts B. Iatrogenic discitis: the role of intravenous antibiotics in prevention and treatment. An experimental study. Spine 1989;14(9):1025-1032

18 Grane P, Josephsson A, Seferlis A, Tullberg T. Septic and aseptic post-operative discitis in the lumbar spine-evaluation by MR imaging. Acta Radiol 1998;39(2):108-115

19 Tronnier V, Schneider R, Kunz U, Albert F, Oldenkott P. Postoperative spondylodiscitis: results of a prospective study about the aetiology of spondylodiscitis after operation for 
lumbar disc herniation. Acta Neurochir (Wien) 1992;117(3/4): 149-152

20 Kemp HB, Jackson JW, Jeremiah JD, Hall AJ. Pyogenic infections occurring primarily in intervertebral discs. J Bone Joint Surg Br 1973;55(4):698-714

21 Barrios C, Ahmed M, Arrótegui J, Björnsson A, Gillström P. Microsurgery versus standard removal of the herniated lumbar disc. A 3-year comparison in 150 cases. Acta Orthop Scand 1990;61(5):399-403

22 Longo UG, Loppini M, Romeo G, Maffulli N, Denaro V. Errors of level in spinal surgery: an evidence-based systematic review. J Bone Joint Surg Br 2012;94(11):1546-1550

23 Iversen E, Nielsen VA, Hansen LG. Prognosis in postoperative discitis. A retrospective study of 111 cases. Acta Orthop Scand 1992;63(3):305-309

24 Hopkinson N, Stevenson J, Benjamin S. A case ascertainment study of septic discitis: clinical, microbiological and radiological features. QJM 2001;94(9):465-470

25 Moon MS, Kim SS, Lee BJ, Moon JL, Sihn JC, Moon SI. Pyogenic discitis following discectomy. J Orthop Surg (Hong Kong) 2012;20(1):11-17

26 Dauch WA. Infection of the intervertebral space following conventional and microsurgical operation on the herniated lumbar intervertebral disc. A controlled clinical trial. Acta Neurochir (Wien) 1986;82(1/2):43-49

27 Thelander U, Larsson S. Quantitation of C-reactive protein levels and erythrocyte sedimentation rate after spinal surgery. Spine 1992;17(4):400-404

28 Kopecky KK, Gilmor RL, Scott JA, Edwards MK. Pitfalls of computed tomography in diagnosis of discitis. Neuroradiology 1985;27(1):57-66

29 Hamdan TA. Postoperative disc space infection after discectomy: a report on thirty-five patients. Int Orthop 2012;36(2):445-450

30 Dunbar JA, Sandoe JA, Rao AS, Crimmins DW, Baig W, Rankine JJ. The MRI appearances of early vertebral osteomyelitis and discitis. Clin Radiol 2010;65(12):974-981

31 Yeom JA, Lee IS, Suh HB, Song YS, Song JW. Magnetic resonance imaging findings of early spondylodiscitis: interpretive challenges and atypical findings. Korean J Radiol 2016;17(5):565-580

32 Rawlings C, Wilkins R, Neurosurgery. Rengachary. New York: McGraw-Hill; 1996
33 Lang R, Folman Y, Ravid M, Bental T, Gepstein R. Penetration of ceftriaxone into the intervertebral disc. J Bone Joint Surg Am 1994;76(5):689-691

34 Tai CC, Want S, Quraishi NA, Batten J, Kalra M, Hughes SP. Antibiotic prophylaxis in surgery of the intervertebral disc. A comparison between gentamicin and cefuroxime. J Bone Joint Surg Br 2002;84(7):1036-1039

35 Jordan J, Konstantinou K, O'Dowd J. Herniated lumbar disc. BMJ Clin Evid 2009;2009:1118

36 Silber JS, Anderson DG, Vaccaro AR, Anderson PA, McCormick $\mathrm{P}$; NASS. Management of postprocedural discitis. Spine J 2002;2(4):279-287

37 Enoch DA, Cargill JS, Laing R, Herbert S, Corrah TW, Brown NM. Value of CT-guided biopsy in the diagnosis of septic discitis. J Clin Pathol 2008;61(6):750-753

38 Yang SC, Fu TS, Chen LH, Chen WJ, Tu YK. Identifying pathogens of spondylodiscitis: percutaneous endoscopy or CT-guided biopsy. Clin Orthop Relat Res 2008;466(12):3086-3092

39 Yang SC, Fu TS, Chen LH, Niu CC, Lai PL, Chen WJ. Percutaneous endoscopic discectomy and drainage for infectious spondylitis. Int Orthop 2007;31(3):367-373

40 Bavinzski G, Schoeggl A, Trattnig S, et al. Microsurgical management of postoperative disc space infection. Neurosurg Rev 2003;26(2):102-107

41 Zou MX, Peng AB, Dai ZH, et al. Postoperative initial single fungal discitis progressively spreading to adjacent multiple segments after lumbar discectomy. Clin Neurol Neurosurg 2015;128:101-106

42 Lee JS, Suh KT. Posterior lumbar interbody fusion with an autogenous iliac crest bone graft in the treatment of pyogenic spondylodiscitis. J Bone Joint Surg Br 2006;88(6):765-770

43 Shetty AP, Aiyer SN, Kanna RM, Maheswaran A, Rajasekaran S. Pyogenic lumbar spondylodiscitis treated with transforaminal lumbar interbody fusion: safety and outcomes. Int Orthop 2016;40(6):1163-1170

44 Blizzard DJ, Hills CP, Isaacs RE, Brown CR. Extreme lateral interbody fusion with posterior instrumentation for spondylodiscitis. J Clin Neurosci 2015;22(11):1758-1761

45 Rawlings CE, III. Wilkins RH, Gallis HA, Goldner JL, Francis R. Postoperative intervertebral disc space infection. Neurosurgery 1983;13(4):371-376 